\title{
Human hair mercury levels in Tucuruí area, State of Pará, Brazil
}

\section{Leino, $T$.}

Elsevier Science BV.

1995

Leino, T. and Lodenius, M. 1995. Human hair mercury levels in Tucuruí area, State of Pará, Brazil. The Science of the Total Environment 175: 119-125.

http://hdl.handle.net/1975/186

Downloaded from Helda, University of Helsinki institutional repository.

This is an electronic reprint of the original article.

This reprint may differ from the original in pagination and typographic detail.

Please cite the original version. 


\title{
Human hair mercury levels in Tucuruí area, State of Pará, Brazil
}

\author{
Tuija Leino, Martin Lodenius* \\ Department of Limnology and Environmental Protection, P.O. Box 27, FIN-00014, University of Helsinki, Helsinki, Finland
}

\begin{abstract}
The environmental mercury contamination at the Tucuruí water reservoir was studied by measuring the amount of mercury in human hair samples collected from fishermen and their families. Samples were also collected from the Parakanã Indian reservation in the vicinity to give information about the background levels in the area. The mercury concentrations in hair samples ranged from 0.9 to $240 \mathrm{mg} / \mathrm{kg}$. The mean value in the main reservoir was $65 \mathrm{mg} / \mathrm{kg}$. Seven values exceeded $100 \mathrm{mg} / \mathrm{kg}$ and 31 values exceeded $50 \mathrm{mg} / \mathrm{kg}$. The hair $\mathrm{Hg}$ concentrations amongst the fishermen in Tucuruí reservoir are high enough to cause health effects. The fetal exposure is especially alarming. Changes in gold mining practises and in the human diet are recommended.
\end{abstract}

Keywords: Mercury; Gold mining; Reservoir; Brazil; Hair; Risk assessment

\section{Introduction}

Mercury is commonly used in gold mining in Amazonia. The Serra Pelada goldfield, situated in Eastern Amazonia, was the most productive of all Brazilian goldfields at its peak in the early 1980s, with over 100000 gold miners. At present, however, there are probably no more than 20000 miners. Based on gold production statistics, it has been calculated that the mercury emissions from Serra Pelada have been c. $590 \mathrm{t}$ between 1980 and $1986[1,2]$.

Downstream of Serra Pelada on the river Tocantins, there is a water reservoir constructed for

\footnotetext{
${ }^{*}$ Corresponding author
}

hydroelectrical power in Tucuruí. The reservoir is the largest in Northern Brazil and its fish is consumed by local fishermen as well as sold in towns even in the delta area of the Amazon, 300 $\mathrm{km}$ away from Tucuruí.

There are two possible causes of mercury contamination in the Tucuru! area: gold mining and the water reservoir itself. Moderate or severe mercury pollution of the Amazonian aquatic ecosystems has been observed in areas with heavy gold mining, with fish mercury values exceeding the Brazilian maximum allowable level of 0.5 $\mathrm{mg} / \mathrm{kg}$ [3-5]. Further, there is evidence of high mercury concentrations in fish in man-made lakes without any known pollution sources.

This study is a part of a larger, Finnish-Brazilian research project studying the environmental mer- 
cury contamination around Tucuruí water reservoir [6].

\section{Material and methods}

\subsection{Study area}

The Tucuruí hydroelectrical power plant is situated about $110 \mathrm{~km}$ to the northeast of Serra Pelada (Fig. 1). It started to operate in 1984. The water reservoir covers $2430 \mathrm{~km}^{2}$ and contains 250 $\mathrm{km}^{2}$ of islands, which are now becoming inhabited. Most of the area was not deforested before the water started to rise and hence there are large amounts of tropical rainforest submerged. The water is rich in nutrient and carries plenty of fish.

The sidebasin lake Caraipé (Fig. 1) is formed from waters of river Caraipé and is almost totally separated from the main reservoir, and hence it is not in direct contact with waters from Serra Pelada gold field.

Some 3350 families totalling over 17300 people lived in the reservoir area at the time before its filling. In addition, thousands of workers from the northeast moved to the area while the dam was under construction and most of them stayed after the work was finished. There are temporary houses on the islands in the reservoir for men, in most of the cases the rest of the family lives in cities like Marab (population in 1985: 133600) and Tucuruí (84000). Around 2000 people are working for the power company and living in Vila permanente near the dam area. However, the total amount of people feeding on the fish from

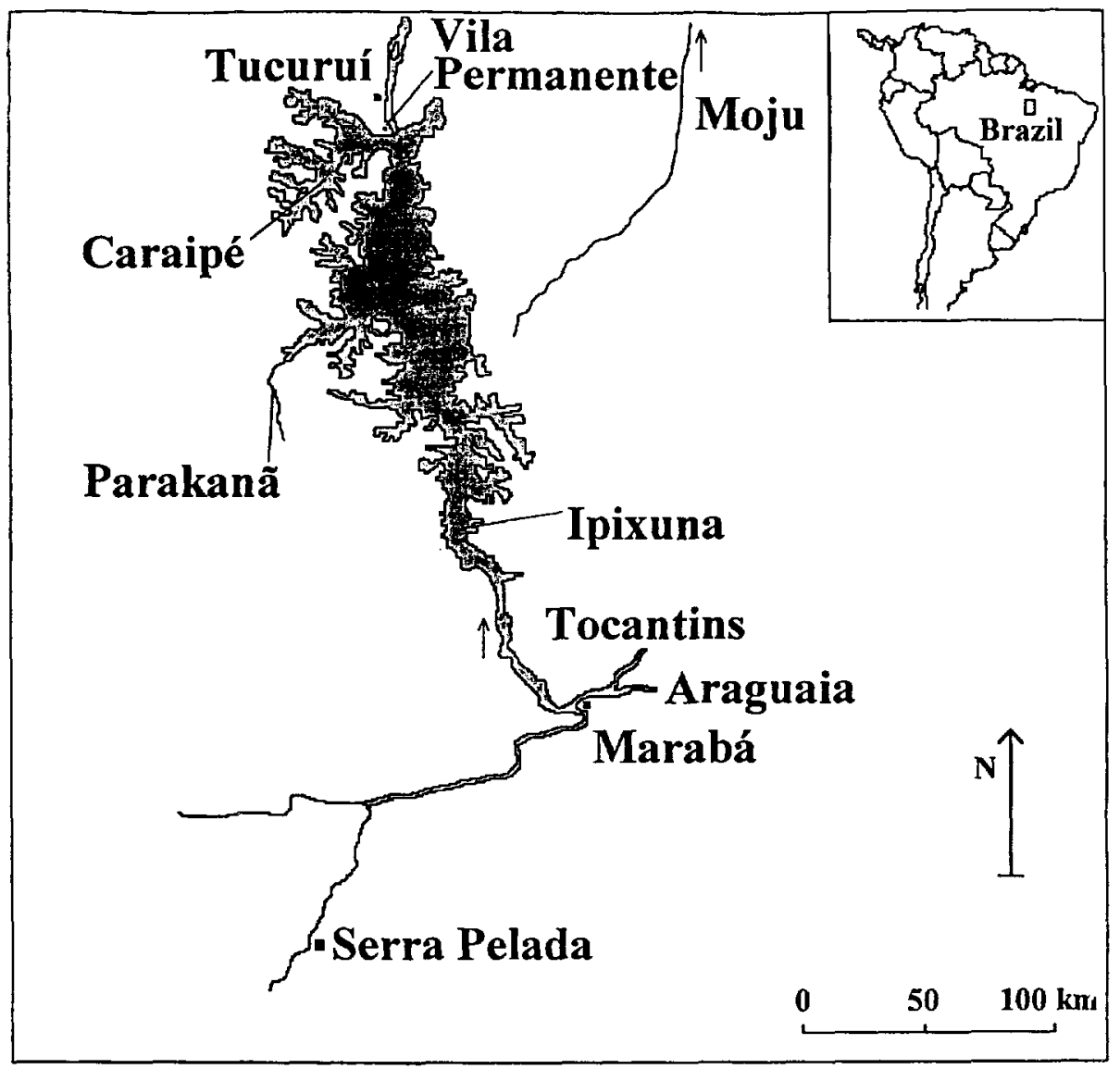

Fig. 1. The study area in Tucuruí area, Brazil. The Caraipé side basin is almost separated from the main basin. 
the reservoir is difficult to estimate as there are no official population records in the area.

In the Tucuruí reservoir, the highest $\mathrm{Hg}$ concentrations were measured in predatory fish [7]. The mean $\mathrm{Hg}$ concentrations of the most commonly eaten fish species at the reservoir ranged from 0.99 to $1.3 \mathrm{mg} / \mathrm{kg}$ [7].

\subsection{Testing of the people}

Symptoms typical of methyl mercury poisoning: glove- and stocking-type sensory disturbance, constriction of visual field and trembling of hands were preliminarily tested with simple field tests used in routine neurological examination: vibration sensory tests with tuning fork, finger perimetry for visual fields and writing or drawing to demonstrate the trembling of hands. Due to poor co-operation, the tests were far from completed with each participant.

\subsection{Analysis of hair samples}

Before the analysis, hair samples were washed successively with acetone, three times with distilled water and again with acetone following the washing schema of Kosta et al. [8]. Each hair sample was divided into at least two parts weighing around $100 \mathrm{mg}$ each, dried at $40-45^{\circ} \mathrm{C}$, and then analysed separately. Five millilitres of strong acid (4:1 of $\mathrm{H}_{2} \mathrm{SO}_{4} / \mathrm{HNO}_{3}$ p.a. grade) were added in an ice bath. The samples were further left to stand for about $6 \mathrm{~h}$ and digested at $85^{\circ} \mathrm{C}$ for $4 \mathrm{~h}$. Roughly $20 \mathrm{ml}$ of $5 \% \mathrm{KMnO}_{4}$ was added. Then the sample was diluted to $100 \mathrm{ml}$ with distilled water and left overnight. The excessive permanganate was reduced by adding hydroxylammonium hydrochloride and the mercury was reduced by stannous chloride and analysed with a Bacharach MAS 50B cold vapour atomic absorption spectrometer (CVAAS) [9]).

The samples were analysed in the laboratory of the Environmental Research Center of Eletronorte at Tucuruí. The accuracy of the analytical method was tested using parallel determinations, and the standard addition method and several samples were taken to the University of Helsinki for calibration of the analysis. Based on these measurements, the analyses were judged reliable, although the results of parallel hair sam- ples were generally $10 \%$ lower in the laboratory of Helsinki than the results from Tucuruí. If the parallel results differed by more than 10 percent, the analysis was repeated if there was enough hair left. Otherwise the result was discarded (two out of 147).

For the statistical testing of areal differences, the nonparametric Kruskal-Wallis test was used primarily followed by the NPAR1WAY procedure. Correlations were calculated with Spearman's coefficients.

\section{Results}

The mean $\mathrm{Hg}$ concentration in the hair of people fishing in the reservoir was $65 \mathrm{mg}$. The average number of weekly fish meals was 14 . The employees of the power company living in Vila ate fish less often than people fishing in the reservoir and the mean mercury concentration in their hair was clearly lower. Parakanã Indians had the lowest mean $\mathrm{Hg}$ concentration in the study (Fig. 2).

The concentration of $\mathrm{Hg}$ in the hair samples correlated positively with the number of weekly fish meals amongst the fishermen who ate predatory fish $(r=0.75$ ). $\mathrm{Hg}$ concentrations in people who ate other kinds of fish did not correlate significantly with the number of weekly fish meals.

The number of women and children was small in this study, but within this group there was also

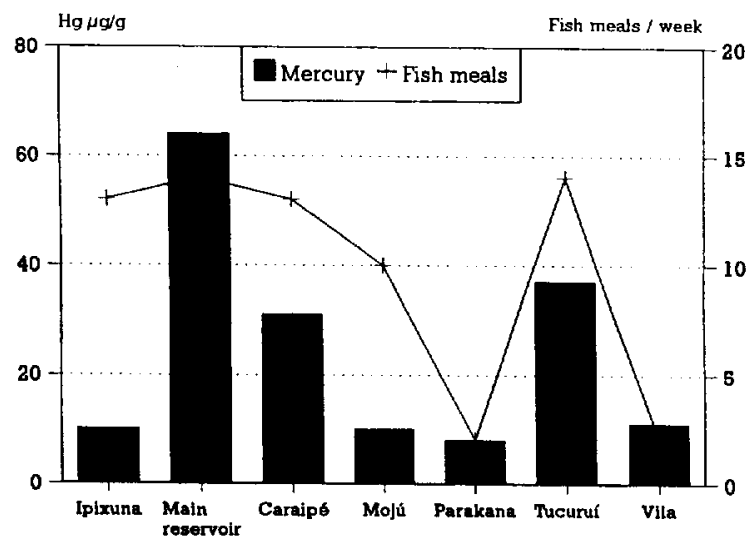

Fig. 2. Mean mercury concentrations in human hair (males only) and the number of weekly fish meals. 


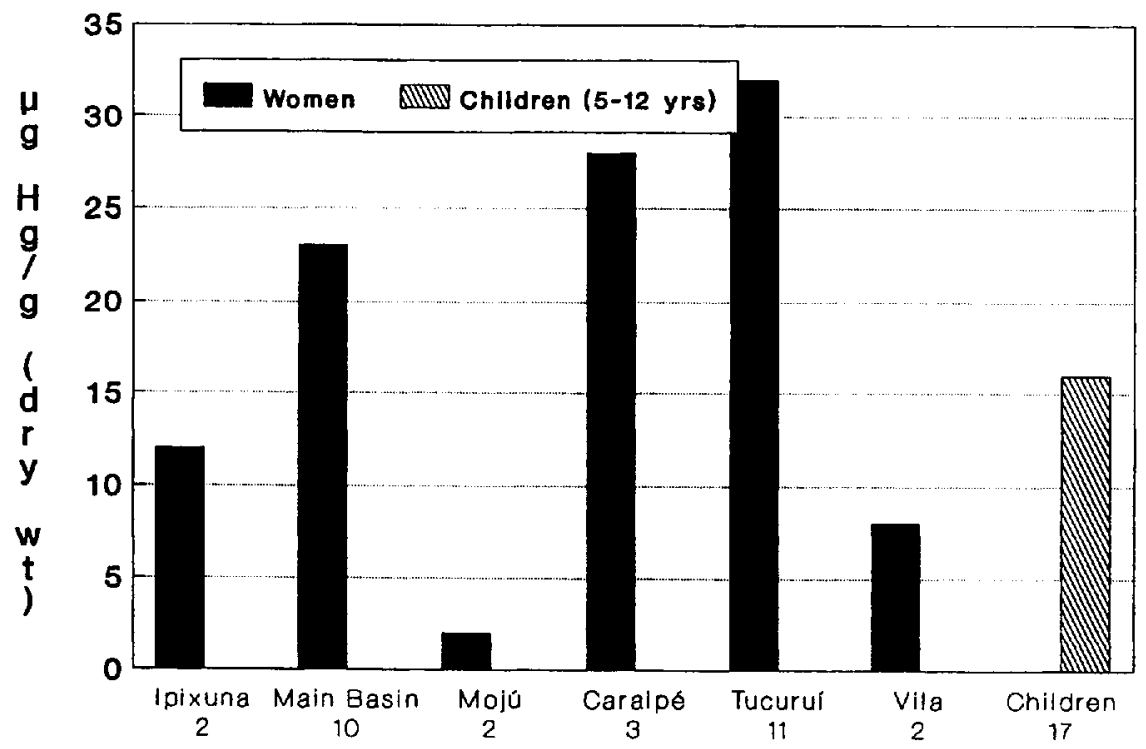

Fig. 3. Mean mercury concentrations in human hair: women and children.

a positive correlation between the number of weekly meals of predatory fish and the $\mathrm{Hg}$ concentration in hair (Fig. 3). Within families, there was no significant difference between sexes (num- ber of couples $=9$ ), although the mean was higher for men than that for women in the whole material.

Weekly fish eaten did not significantly differ $(P$

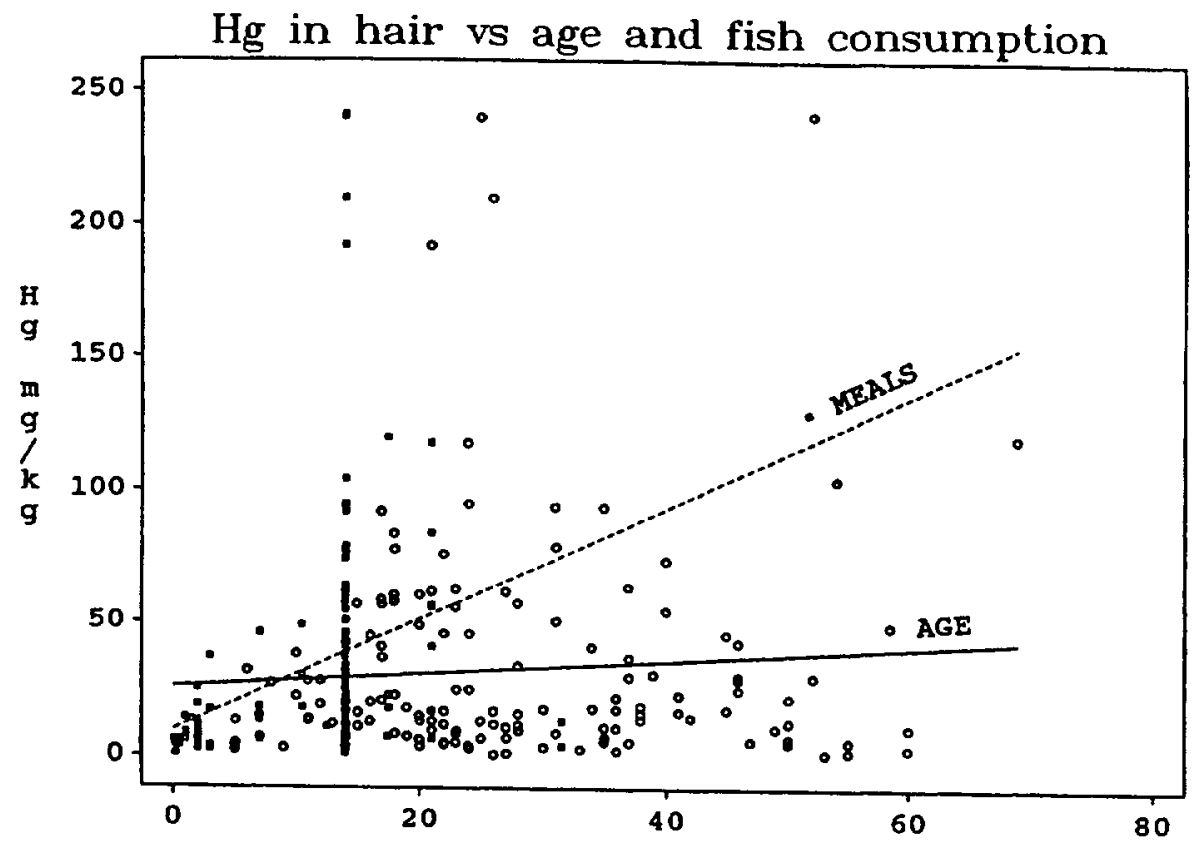

Fig. 4. Linear regression between hair mercury concentrations and age of the people and fish consumption (meals per week), respectively. 
$=0.7$ ) between the following four areas: the beginning of the reservoir (Ipixuna), the main reservoir, the lake Caraipé and the downstream city of Tucuruí (Fig. 1, Table 1); hence the $\mathrm{Hg}$ concentrations in hair were compared between these areas to find out the most contaminated areas. In respect of the hair $\mathrm{Hg}$ concentrations only the beginning of the reservoir differed significantly from the other three areas. This can partly be explained by the fact that at the beginning of the reservoir the most commonly eaten fish is herbivorous. These species were forbidden to fish during the period of the study and therefore people did not admit the consumption of that fish but included these fish in the group of predatory fish. The concentrations in herbivorous fish were clearly lower than in predatory fish [7].

Indians, as well as employees of the power company living in Vila ate fish less often than people fishing in the reservoir. The $\mathrm{Hg}$ concentrations in these two groups were clearly lower than that for the fishermen (Fig. 2).

The concentration of $\mathrm{Hg}$ in the hair samples correlated positively with the number of weekly fish meals amongst the reservoir fishermen who ate predatory fish $(r=0.75, N=48) . \mathrm{Hg}$ concentrations in people who ate other kinds of fish did not correlate significantly with the number of weekly fish meals. The correlation between age and mercury concentration in hair was weak (Fig. 4).

No clear clinical symptoms of methyl mercury poisoning (Minamata disease) were found. The survey, however, was far from reliable in showing possible symptoms as most of the people in this study did not allow any further neurological examination.

\section{Discussion}

As we consider fish to be the main route of $\mathrm{Hg}$ into the human body it is possible to count the amount of fish needed to be eaten each day for the mercury concentration in hair to rise to a certain level. For a $60-\mathrm{kg}$ man to reach a hair $\mathrm{Hg}$ concentration of $50 \mathrm{mg} / \mathrm{kg}$ he needs to ingest 0.3 $\mathrm{mg} \mathrm{Hg}$ daily according to a Japanese study of 765 people [10]. Swedish experts have obtained similar results $[11,12]$. To ingest this amount of mercury from fish containing $1 \mathrm{mg} \mathrm{Hg}$ per kilogram, one has to eat $330 \mathrm{~g}$ of fish daily. In fish caught from Tucuruí these amounts were common and in this study fishermen generally ate two daily meals of fish. The weight of fresh fish per meal should have been $165 \mathrm{~g}$ which seems to be a probable amount of fish to be eaten.

In this study the hair $\mathrm{Hg}$ concentrations are clearly higher than in other studies made in gold mining areas. In Carajás, in the state of Pará, Fernandes et al. found $\mathrm{Hg}$ concentrations of $0.25-15.7 \mathrm{mg} / \mathrm{kg}$ in hair samples [13].

The Hg concentrations in this study are higher than in studies performed in other reservoirs, if we consider lake Caraipé to represent purely the contamination due to the reservoir and hence compare the literature values from other reservoirs with the values from Caraipé. In Finland the

Table 1

Mercury concentrations ( $\mu \mathrm{g} \mathrm{g}^{-1}$ ) of the adult population in different areas

\begin{tabular}{|c|c|c|c|c|c|c|c|}
\hline & \multirow[t]{2}{*}{$N$} & \multirow{2}{*}{$\begin{array}{c}\text { Age } \\
\text { (years) }\end{array}$} & \multirow{2}{*}{$\begin{array}{l}\text { Fish meals } \\
\text { per week }\end{array}$} & \multicolumn{4}{|l|}{$\mathrm{Hg}$} \\
\hline & & & & Mean & Range & S.D. & Median \\
\hline Main reservoir & 45 & 28 & 14 & 65 & $6-240$ & 58 & 51 \\
\hline Tucuruí & 16 & 21 & 14 & 37 & $11-64$ & 21 & 33 \\
\hline Caraipé & 11 & 32 & 13 & 31 & $14-74$ & 19 & 23 \\
\hline Mojú & 8 & 27 & 10 & 10 & $2.3-19$ & 6.1 & 11 \\
\hline Parakanã & 12 & 32 & 2 & 8.5 & $3.3-12$ & 2.8 & 8.5 \\
\hline Ipixuna & 18 & 32 & 13 & 10 & $1.2-34$ & 9.7 & 7.2 \\
\hline Vila & 15 & 33 & 1 & 11 & $0.9-37$ & 9.8 & 6.0 \\
\hline Total & 125 & 29 & 11 & 35 & $0.9-240$ & & 29 \\
\hline
\end{tabular}


concentrations in human hair in the northern reservoirs have been between $0.02-35 \mathrm{mg} / \mathrm{kg}$; mean in the Lokka reservoir was $4.4 \mathrm{mg} / \mathrm{kg}$ and in the Porttipahta reservoir the mean was 5.9 $\mathrm{mg} / \mathrm{kg}[14]$.

In South America, values have generally been lower than the background values in this study. Amongst Yanomami Indians mercury concentrations in hair were between $0.3-1.4 \mathrm{mg} / \mathrm{kg}$ (mean $=1.0 \mathrm{mg} / \mathrm{kg}$ ) [15]. In Cumarú gold mining area, which is also situated in Par, the mercury concentrations in the hair samples were between $1.5-13.7 \mathrm{mg} / \mathrm{kg}$ (mean 5.1) and in the area of Cachoeiro the values were between 2.0-69.0 $\mathrm{mg} / \mathrm{kg}$ (mean 11.5) [16]. In the northeastern Bolivian Amazon, Japanese immigrants had hair mercury values as high as $40 \mathrm{mg} / \mathrm{kg}$ but the mean was $4.5 \mathrm{mg} / \mathrm{kg}$. In Brazil the highest value was 9.2 $\mathrm{mg} / \mathrm{kg}$ (mean $=2.2 \mathrm{mg} / \mathrm{kg}$ ) amongst the men in that same study [17]. The differences between previous studies and this work could be explained by the smaller role of fish in daily diet in gold mining areas, where people generally eat more meat. As we studied fishermen at the reservoir, the daily meals mostly consisted of fish.

The background values in this study can be criticized however, because mercury can also be expected to be carried by air in the area of the Parakanā Indian reservation. It is, however, difficult to find people who are eating fish in Amazonia nowadays, and who would not have been in contact with mercury at all.

According to data reported on dose-effect relationships in humans, clearly defined neurological symptoms in adults are not expected to appear at $\mathrm{Hg}$ concentrations in hair of $50-125 \mathrm{mg} / \mathrm{kg}$. Adult people with $50 \mathrm{mg} / \mathrm{kg}$ mercury in hair, corresponding to a daily intake of $0.2 \mathrm{mg} \mathrm{Hg}$, would have a low risk of neurological damage. However, the fetus is more sensitive, and psychomotor retardation has become detectable with maternal hair concentrations as low as $20 \mathrm{mg} / \mathrm{kg}$ during pregnancy $[18,19]$. A New Zealand study reported evidence of developmental retardation in 4-yearold children even at average maternal hair $\mathrm{Hg}$ levels during pregnancy ranging from 6 to 86 $\mathrm{mg} / \mathrm{kg}$ (the second highest value was $19.6 \mathrm{mg} / \mathrm{kg}$
[20]). Concentrations above these levels were common in this study.

According to the results of this study the hair $\mathrm{Hg}$ concentrations amongst the fishermen in $\mathrm{Tu}$ curuí reservoir and its surrounding area are high enough to cause health effects. Methyl mercury poisoning can be estimated to threaten thousands of people in the area. Further studies are needed, and in particular, women at fertile age should be monitored carefully to prevent possible hazards for the unborn children. The field could also be open for evaluating the possible symptoms caused by chronic $\mathrm{Hg}$ exposure.

It is very important to reduce the emissions of mercury into air, soil and water by changing gold mining practises. It is difficult to restrict the use of fish in the diet in the area because fish is the main protein source especially in the fishermen's families, and cannot be substituted with meat for economic reasons. However, a change from predatory to herbivorous fish species could significantly decrease the intake of methyl mercury.

\section{Acknowledgements}

This work was part of a research project carried out by I. Aula, H. Braunschweiler, T. Hatanaka, A. Juras, T. Leino, M. Lodenius, I. Malin and P. Porvari. We are indebted to the Finnish Development Agency (FINNIDA), to the Academy of Finland and to Eletronorte Ltd. for financial and technical support.

\section{References}

[1] D. Cleary, Anatomy of the Amazon Gold Rush, McMillan, London, 1990, p. 245.

[2] W.C. Pfeiffer and L.D. Lacerda, Mercury inputs into the Amazon region, Brazil. Environ. Technol. Lett., 9 (1988) $325-330$.

[3] L.D. Lacerda, W.C. Pfeiffer, A.T. Ott and E.G. Silveira, Mercury contamination in the Madeira river, Amazon - $\mathrm{Hg}$ inputs to the environment. Biotropica, 21(1) (1989) 91-93.

[4] O. Malm, W.C. Pfeiffer, C.M.M. Souza and R. Reuther, Mercury pollution due to gold mining in the Madeira river basin, Brazil. Ambio, 19 (1990) 11-15.

[5] H. Akagi, O. Malm, M. Harada, F. Branches, W. Pfeiffer and $\mathbf{H}$. Kato, Methylmercury pollution in the Tabajos river, Amazon, Brazil. Proceedings of an International 
Symposium Epidemiological Sudies on Environmental Pollution and Health Effects of Methyl Mercury, Kumamoto, 2 October 1992, 1993, pp. 50-55.

[6] I. Aula, H. Braunschweiler, T. Leino, I. Malin, P. Porvari, T. Hatanaka, M. Lodenius and A. Juras, Levels of mercury in the Tucuruí reservoir and its surrounding area in Pará, Brazil. Watras C. and J. Huckabee (eds): Mercury pollution, Integration and synthesis. Lewis Publ. (Boca Raton - Ann Arbor - London -Tokyo), 1994, pp 21-40.

[7] P. Porvari, Mercury levels of fish in Tucurui hydroelectric reservoir and in river Mojú in Amazonia, in the state of Pará, Brazil. Sci. Total Environ., 175 (1995) 109-117.

[8] L. Kosta, M. Horvat, A.R. Byrne and P. Stegnar, Determination of methylmercury, total mercury and sele. nium in human hair by gas liquid chromatography and cold vapour atomic absorption spectrophotometry. Proceedings of WHO/FAO/UNEP Meeting Mediterranean Health Related Environmental Quality Criteria, Bled, 12-16 September 1989, p. 13.

[9] P. Nuorteva, S. Autio, J. Lehtonen, A. Lepistö, S. Ojala, A. Seppänen, E. Tulisalo, P. Veide, J. Viipuri and R. Willamo, Levels of iron, aluminium, zinc, cadmium and mercury in plants growing in the surroundings of an acidified and a non-acidified lake in Espoo, Finland. Ann. Bot. Fennici, 23 (1986) 333-340.

[10] K. Kojima and T. Araka, Normal $\mathrm{Hg}$ Levels in Food in Japan, Stencil, Tokyo, 1972.

[11] G. Birke, A.G. Johnels, L.O. Plantin, B. Sjöstrand and $\mathrm{T}$. Westermark, $\mathrm{Hg}$ poisoning through eating fish? Läkartidningen, 64 (1967) 3628-3637.
[12] Swedish Expert Group, Methylmercury in fish. Nord. Hyg. Tidskr. (Stockholm), Suppl. 4 (1971) 19-364.

[13] R. Fernandes, A.F. Guimaraes, E.D. Bidone, L.D. Lacerda and W.C. Pfeiffer, Monitoramento do mercurio na area do projeto Carajás da companhia Vale do Rio Doce (CVRD), Estudo do Pará, Brasil. Proceedings Control of Pollution by $\mathrm{Hg}$ in the Amazon, Belém, 4-6 December 1989, $26 \mathrm{pp}$.

[14] M. Lodenius and A. Seppänen, Hair mercury contents and fish eating habits of people living near a Finnish man-made lake. Chemosphere, 11 (1982) 755-759.

[15] L.H. Hecker, H.E. Allen, B.D. Dinman and J.V. Neel, Heavy metal levels in acculturated and unacculturated populations. Arch. Environ. Health, 29 (1974) 181-185.

[16] R.C. Couto, V.M. Camara and P.C. Sabroza, Intoxicacao mercurial: resultados preliminares em duas areas garimpeiras no Estudo do Pará. Pará Desenvolvimento, 23 (1988) 63-67.

[17] S. Tsugane and $H$. Kundo, The mercury content of hair of Japanese immigrants in various locations in South America. Sci. Total Environ., 63 (1987) 69-76.

[18] WHO, Methylmercury. Environmental Health Criteria 101, WHO, Geneva, 1990, $141 \mathrm{pp}$.

[19] T.W. Clarkson, Human health risks from methylmercury in fish. Environ. Toxicol. Chem., 9 (1990) 957.

[20] T. Kjellström, P. Kennedy, S. Wallis and C. Mantell, Physical and mental development of children with prenatal exposure to mercury from fish. Stage 1: preliminary tests at age 4. Natl. Swed. Environ. Prot. Board, Rep. 3080 (1986) 1-96. 